\title{
The stock genetic structure of two Sparidae species, Diplodus vulgaris and Lithognathus mormyrus, in the Mediterranean Sea
}

\author{
M. Arculeo ${ }^{\text {a,* }}$, S. Lo Brutto ${ }^{\text {a }}$, M. Sirna-Terranova ${ }^{\text {a }}$, T. Maggio ${ }^{\text {a }}$, \\ L. Cannizzaro ${ }^{\text {b }}$, N. Parrinello ${ }^{\text {a }}$ \\ a Dipartimento di Biologia Animale, Università di Palermo, Via Archirafi 18, 90123 Palermo, Italy \\ ${ }^{\mathrm{b}}$ IRMA-CNR, Via L. Vaccara 61, Mazara del Vallo, Trapani, Italy
}

Received 3 April 2002; received in revised form 12 February 2003; accepted 27 February 2003

\begin{abstract}
Polyacrilamide gel electrophoresis (PAGE) of allozymes was used to investigate the intraspecies genetic variation and the genetic stock structure of Diplodus vulgaris and Lithognathus mormyrus captured from eight localities in the Mediterranean Sea. Twenty-two and 20 putative enzyme-coding loci were examined, respectively, in D. vulgaris and L. mormyrus. Polymorphic loci at the $95 \%$ level were used to assess the allozyme variability in D. vulgaris (AAT-2*, EST-1*, GLDH*, $\left.P E P B-2^{*}, P G I-2^{*}, P G M^{*}, S D H^{*}\right)$ and L. mormyrus (AAT-2* EST-1* $\left.{ }^{*} G L D H^{*}, M D H-2^{*}, P G I-2^{*}, P G M^{*}\right)$. The proportion of polymorphic loci in both species ranged from 0.31 (D. vulgaris) to 0.30 (L. mormyrus), and the observed and expected mean heterozygosity varied between 0.082 and 0.093 (D. vulgaris) and between 0.069 and 0.072 (L. mormyrus). The mean value of observed heterozygosity in $D$. vulgaris showed a deficit of heterozygosites, thereby indicating a Wahlund effect in the samples examined. Significant genetic differentiation (mean value of $\theta=0.013, p<0.005$ ) was found in $D$. vulgaris indicating an intraspecific genetic substructure among the samples examined, whereas the mean value of $\theta=$ $0.001, p>0.05$ found in L. mormyrus showed a high degree of genetic homogeneity. The results showed the presence of distinct subpopulations of $D$. vulgaris among the sampled sites, and suggested that analysis of allozymes may provide important information on the genetic stock structure of these two sparids to ensure sustainable management of these species.

(C) 2003 Elsevier Science B.V. All rights reserved.
\end{abstract}

Keywords: Stock structure; Allozymes; Diplodus vulgaris; Lithognathus mormyrus; Sparidae

\section{Introduction}

The Sparidae family is represented in Mediterranean Sea by 10 genera and 22 species that usually inhabit coastal areas, and produce pelagic eggs and

\footnotetext{
* Corresponding author. Tel.: +39-091-6177160; fax: +39-091-6230144.

E-mail address: marculeo@unipa.it (M. Arculeo).
}

larvae. The species Diplodus vulgaris and Lithognathus mormyrus, belonging to this family, are commercially important demersal fish which are caught in a bathymetric range of $3-100 \mathrm{~m}$. D. vulgaris is distributed along Mediterranean coasts, the Atlantic Ocean and from the Gulf of Guascogna to Senegal. It lives on rocky and sandy bottoms, close to the habitat of the marine plant Posidonia oceanica or in lagoons. L. mormyrus is the only species of its genus and is 
present on the sandy bottoms of Mediterranean Sea, Atlantic Ocean, Western Indian Ocean and Red Sea.

In recent years many Sparidae species have been investigated with regard to reproduction, ethology and growth. However, little information concerning the assessment of the productivity potential and the genetic structure is available. The few studies of allozyme variation of Sparidae species have focused mainly on finding species specific isozyme markers (Alarcón and Alvarez, 1999; Basaglia, 1991; Reina et al., 1994), but less have focused on intraspecific genetic variation and stock assessment. Only Arculeo et al. (1999) reported preliminary data comparing growth parameters and electrophoretic approaches in L. mormyrus caught along the Sicilian and Greek coasts where no significant differences between sample sites were found. Successively, stock and population dynamics of $D$. vulgaris and L. mormyrus were assessed by an age-based virtual population analysis (ACA-VPA) along the $\mathrm{Si}$ cilian and Aegean coasts (Cannizzaro, Final Report EC, 2000, pers. comm.). Those preliminary results indicated that catch effort in the areas analysed was effected in different ways, and that both species were composed mainly of young individuals, and suffer from the fishing activities.

The use of molecular markers applied to stock assessment has often cast light on population substructure, and given useful information for the management of fishery resources (Carvalho and Hauser, 1995). Because population genetic methods offer new tools for investigating genetic stock structure, which is of primary interest in fisheries management, we analyse in this paper the genetic population structure of $D$. vulgaris and improve information on the genetic variation of L. mormyrus in the Mediterranean Sea.

\section{Materials and methods}

\subsection{Sample collection and electrophoresis}

A total of 400 specimens of $D$. vulgaris from seven localities and 470 specimens of L. mormyrus from six localities was sampled within the Mediterranean basin. The localities were: Livorno and Castellammare del Golfo in the Tyrrhenian Sea; Selinunte in the Channel of Sicily; Siracusa in the Ionian Sea; Ancona and Trieste in the Adriatic Sea; and Kavala in the Aegean Sea
(Fig. 1). Samples were taken from small boats operating in artisanal fisheries by means of trammel nets at depths of between 20 and $30 \mathrm{mt}$. Once caught, the fish were kept frozen at $-20^{\circ} \mathrm{C}$ until the organs had been removed.

Allozyme electrophoresis was performed. Liver, eye and muscle tissue was homogenised in two volumes of distilled water at $4{ }^{\circ} \mathrm{C}$, centrifuged at $25,000 \times g$ at $4{ }^{\circ} \mathrm{C}$ for $1 \mathrm{~h}$, and the supernatant used for polyacrylamide gel electrophoresis (PAGE) as described by Davis (1964). The homogenates not processed immediately were stored at $-80^{\circ} \mathrm{C}$. Buffers and staining procedures were adapted from Richardson et al. (1986).

A set of enzymes with a clear polymorphic zymogram on the gel was chosen. The loci used for analysis were scored from the following enzyme stainings: alcohol dehydrogenase (ADH, E. C. 1.1.1.1), aspartate aminotransferase (AAT, E. C. 2.6.1.1), esterases (EST, E. C. 3.1.1.1), fumarase (FUM, E. C. 4.2.1.2), glucose dehydrogenase (GLDH, E. C. 1.1.1.47), glucose 6-phosphate dehydrogenase (G6PD, E. C. 1.1.1.49), lactate dehydrogenase (LDH, E. C. 1.1.1.27), malate dehydrogenase (MDH, E. C. 1.1.1.37), peptidases (PEP-A and PEP-B, E. C. 3.4.11), phosphoglucoisomerase (PGI, E. C. 5.3.1.9), phosphoglucomutase (PGM, E. C. 2.7.5.1), sorbitol dehydrogenase (SDH, E. C. 1.1.1.14), superoxide dismutase (SOD, E. C. 1.15.1.1), and xanthine dehydrogenase (XDH, E. C. 1.1.1.204). The detection of isoenzymes and nomenclature of locus designation were performed according to Shaklee et al. (1990). Alleles were designated by their electrophoretic mobilities relative to the cathodal mobility of the most common allele, which was designated as 100 .

\subsection{Statistics}

Direct count observed heterozygosity $(\mathrm{Ho})$ and unbiased expected heterozygosity $(\mathrm{He})$ (Nei, 1978) were calculated over all the examined loci. Deviation from the Hardy-Weinberg $(\mathrm{H}-\mathrm{W})$ equilibrium for each locus was assessed using an exact test calculated by GENEPOP package, and $p$-values were also compared to theoretical $p$-values obtained by the sequential Bonferroni procedure (Lessions, 1992). The variation in allelic frequencies was quantified using the $F$-statistics $(f, F, \theta)$ of Weir and Cockerham 


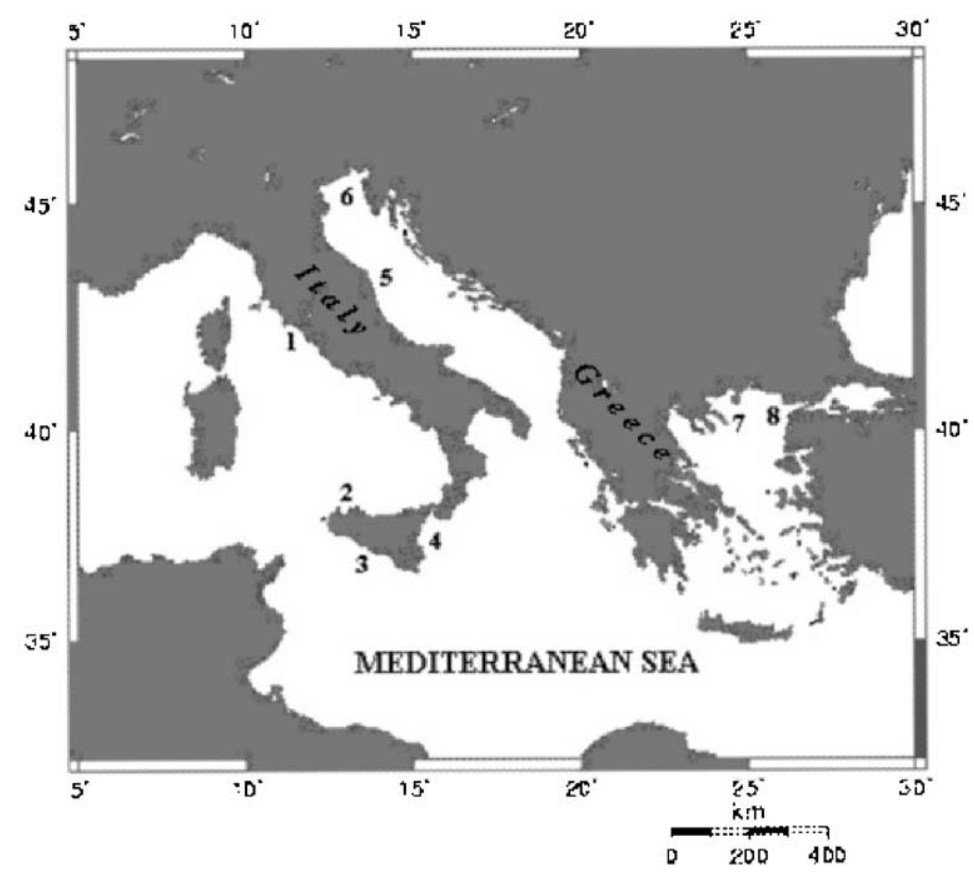

Fig. 1. Localities where samples were caught: Livorno (1) and Castellammare del Golfo (2) in the Tyrrhenian Sea; Selinunte (3) in the Channel of Sicily; Siracusa (4) in the Ionian Sea; Ancona (5) and Trieste (6) in the Adriatic Sea; and Kavala $(7,8)$ in the Aegean Sea.

(1984) per loci over samples. $f, F$ and $\theta$ corresponds, respectively, to Wrigth's $F_{\text {is }}, F_{\text {it }}$ and $F_{\text {st }}$, which are the correlation of alleles within the single sample $\left(F_{\text {is }}\right)$, the correlation of alleles within the total samples $\left(F_{\mathrm{it}}\right)$ and the standardised variance in allele frequencies among samples $\left(F_{\mathrm{st}}\right)$ that is a measure of the degree of genetic differentiation. Their statistical significance of departures from zero was tested using permutations for each locus and for all the loci (using the FSTAT program; Goudet, 1995). Heterogeneity was also calculated by a pairwise comparison between samples and its significance tested using Fisher's exact test method, as computed by the GENEPOP software (Raymond and Rousset, 1995).

To examine the distribution of heterogeneity among the samples of both species, genetic distances (Nei, 1978) were calculated and clustered by NJ algorithm using the MEGA program version 2.1 (Kumar et al., 2001). Bootstrapping with replicates encompassing 100 data sets (Felsenstein, 1985) was performed to investigate the robustness of nodes in each cluster.

\section{Results}

\subsection{Diplodus vulgaris}

Twenty-two loci were scored, 15 of which were monomorphic $\left(A A T^{*}, F U M-1,2^{*}, G 6 P D-1,2^{*}\right.$, LDH-1,2*, MDH-1,2,3*, PEPA-1,2*, PGI-1* and $\left.S O D^{*}\right)$ at a level of $95 \%$. Seven polymorphic loci were identified: $A A T-2^{*}, E S T-1^{*}, G L D H^{*}, P E P B-2^{*}$, $P G I-2^{*}, P^{*} M^{*}$ and $S D H^{*}$; of these $E S T-1^{*}, G L D H^{*}$ and $S D H^{*}$ were highly variable, representing 13,7 and 8 alleles, respectively (Table 1 ). The mean number of alleles per locus was 6.1.

Allelic frequencies for the seven scored polymorphic loci are listed in Table 1. Observed $(\mathrm{Ho})$ and expected $(\mathrm{He})$ heterozygosity plus the $\mathrm{H}-\mathrm{W}$ test are shown in Table 2. On average, the observed heterozygosity (mean value calculated on monomorphic and polymorphic loci) was 0.082 , a lower value than the expected heterozygosity (0.093). The AAT-2* $E S T^{*}$, $G L D H^{*}, P E P B-2^{*}$ and $S D H^{*}$ loci deviated from the Hardy-Weinberg equilibrium (Table 2). After using 
Table 1

Frequencies of alleles found for each locus among the samples of D. vulgaris

\begin{tabular}{|c|c|c|c|c|c|c|c|c|c|}
\hline \multirow[t]{2}{*}{ Locus } & \multirow[t]{2}{*}{ Alleles } & & $\begin{array}{l}\text { Tyrrhenian } \\
\text { Sea I }\end{array}$ & $\begin{array}{l}\text { Tyrrhenian } \\
\text { Sea II }\end{array}$ & $\begin{array}{l}\text { Channel } \\
\text { of Sicily }\end{array}$ & $\begin{array}{l}\text { Ionian } \\
\text { Sea }\end{array}$ & $\begin{array}{l}\text { Adriatic } \\
\text { Sea II }\end{array}$ & $\begin{array}{l}\text { Aegean } \\
\text { Sea I }\end{array}$ & $\begin{array}{l}\text { Aegean } \\
\text { Sea II }\end{array}$ \\
\hline & & & st. $1^{\mathrm{a}}$ & st. 2 & st. 3 & st. 4 & st. 6 & st. 7 & st. 8 \\
\hline \multirow[t]{5}{*}{$A A T-2^{*}$} & & $N^{\mathrm{b}}$ & & 84 & 25 & 40 & & 47 & 34 \\
\hline & 62 & & n.s. ${ }^{\mathrm{c}}$ & 0.060 & 0.404 & 0.025 & n.s. & & \\
\hline & 85 & & & 0.137 & 0.260 & 0.163 & & 0.160 & 0.162 \\
\hline & 100 & & & 0.833 & 0.720 & 0.788 & & 0.830 & 0.824 \\
\hline & 116 & & & 0.024 & 0.020 & 0.025 & & 0.011 & 0.015 \\
\hline \multirow[t]{14}{*}{$E S T-1^{*}$} & & $N$ & 42 & 87 & 35 & 40 & & 41 & 41 \\
\hline & 93 & & 0.012 & 0.006 & 0.014 & 0.025 & 0.053 & & 0.024 \\
\hline & 96 & & 0.048 & 0.017 & 0.043 & 0.025 & & 0.061 & 0.012 \\
\hline & 97 & & & 0.023 & 0.029 & 0.063 & & 0.061 & \\
\hline & 98 & & 0.190 & 0.126 & 0.014 & 0.063 & & 0.122 & 0.085 \\
\hline & 100 & & 0.476 & 0.483 & 0.500 & 0.463 & 0.263 & 0.451 & 0.500 \\
\hline & 101 & & 0.083 & 0.017 & 0.014 & 0.088 & 0.053 & 0.049 & 0.037 \\
\hline & 102 & & 0.119 & 0.155 & 0.114 & 0.125 & 0.053 & 0.061 & 0.146 \\
\hline & 103 & & & 0.023 & 0.043 & & 0.316 & 0.061 & 0.049 \\
\hline & 104 & & & 0.046 & 0.071 & 0.088 & 0.105 & 0.061 & 0.098 \\
\hline & 105 & & 0.012 & 0.046 & 0.100 & & 0.105 & 0.037 & 0.024 \\
\hline & 107 & & 0.012 & 0.006 & 0.043 & & & & \\
\hline & 112 & & 0.012 & 0.011 & 0.014 & & 0.053 & 0.012 & 0.012 \\
\hline & 123 & & 0.036 & 0.040 & & 0.063 & & 0.024 & 0.012 \\
\hline \multirow[t]{8}{*}{$G L D H^{*}$} & & $N$ & 38 & 78 & 36 & 42 & & 49 & 43 \\
\hline & 90 & & 0.013 & & 0.042 & 0.024 & & 0.031 & \\
\hline & 93 & & 0.118 & & 0.125 & 0.036 & & 0.010 & \\
\hline & 100 & & 0.474 & 0.590 & 0.500 & 0.524 & 0.705 & 0.592 & 0.558 \\
\hline & 107 & & 0.013 & 0.032 & 0.028 & 0.107 & 0.159 & 0.051 & 0.128 \\
\hline & 110 & & 0.342 & 0.340 & 0.306 & 0.262 & & 0.286 & 0.198 \\
\hline & 122 & & 0.039 & 0.038 & & 0.048 & 0.136 & 0.031 & 0.093 \\
\hline & & & & & & & & & 0.023 \\
\hline \multirow[t]{4}{*}{$P E P B-2^{*}$} & & $N$ & & & & & & & \\
\hline & & & 0.011 & 0.012 & & 0.022 & & 0.020 & 0.011 \\
\hline & & & 0.943 & 0.959 & 0.971 & 0.967 & 0.900 & 0.929 & 0.944 \\
\hline & & & 0.045 & 0.011 & 0.029 & 0.011 & 0.051 & 0.051 & 0.044 \\
\hline \multirow[t]{6}{*}{ PGI-2* } & & $N$ & 44 & 95 & 42 & 47 & & 49 & 45 \\
\hline & 80 & & & 0.011 & 0.060 & & & & \\
\hline & 92 & & & 0.011 & 0.024 & 0.011 & & & 0.011 \\
\hline & 100 & & 1.000 & 0.963 & 0.905 & 0.989 & 0.980 & 0.969 & 0.978 \\
\hline & 105 & & & 0.011 & & & 0.020 & 0.031 & \\
\hline & 110 & & & 0.005 & 0.012 & & & & 0.011 \\
\hline \multirow[t]{4}{*}{$P G M^{*}$} & & $N$ & 44 & 96 & 42 & 47 & & 49 & 45 \\
\hline & 90 & & 0.011 & 0.005 & & & 0.001 & 0.020 & \\
\hline & 100 & & 0.966 & 0.979 & 0.964 & 0.989 & 0.968 & 0.969 & 0.989 \\
\hline & 110 & & 0.023 & 0.016 & 0.036 & 0.011 & 0.031 & 0.010 & 0.011 \\
\hline \multirow[t]{9}{*}{$S D H^{*}$} & & $N$ & 32 & 91 & 31 & 38 & & 45 & 36 \\
\hline & 60 & & & & & & 0.033 & 0.011 & 0.028 \\
\hline & 71 & & & 0.005 & & 0.026 & & 0.011 & \\
\hline & 87 & & & & & & & 0.011 & 0.014 \\
\hline & 100 & & 0.688 & 0.731 & 0.629 & 0.605 & 0.733 & 0.733 & 0.625 \\
\hline & 123 & & 0.031 & 0.038 & 0.032 & 0.026 & 0.022 & 0.022 & \\
\hline & 131 & & 0.281 & 0.203 & 0.339 & 0.329 & 0.200 & 0.200 & 0.306 \\
\hline & 165 & & & 0.022 & & & & & 0.014 \\
\hline & 176 & & & & & 0.013 & & 0.011 & 0.014 \\
\hline
\end{tabular}

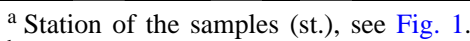

${ }^{\mathrm{b}}$ Number of genotypes scored.

${ }^{\mathrm{c}}$ Not scored. 
Table 2

Observed $(\mathrm{Ho})$ and unbiased expected $(\mathrm{He})$ heterozygosity for each locus in $\mathrm{D}$. vulgaris

\begin{tabular}{|c|c|c|c|c|c|c|c|c|}
\hline \multirow[t]{2}{*}{ Locus } & & $\begin{array}{l}\text { Tyrrhenian } \\
\text { Sea I }\end{array}$ & $\begin{array}{l}\text { Tyrrhenian } \\
\text { Sea II }\end{array}$ & $\begin{array}{l}\text { Channel } \\
\text { of Sicily }\end{array}$ & $\begin{array}{l}\text { Ionian } \\
\text { Sea }\end{array}$ & $\begin{array}{l}\text { Adriatic } \\
\text { Sea II }\end{array}$ & $\begin{array}{l}\text { Aegean } \\
\text { Sea I }\end{array}$ & $\begin{array}{l}\text { Aegean } \\
\text { Sea II }\end{array}$ \\
\hline & & st. $1^{\mathrm{a}}$ & st. 2 & st. 3 & st. 4 & st. 6 & st. 7 & st. 8 \\
\hline \multirow[t]{2}{*}{$A A T-2^{*}$} & $\mathrm{He}$ & n.s. ${ }^{b}$ & 0.288 & 0.422 & 0.357 & n.s. & 0.289 & 0.300 \\
\hline & $\mathrm{Ho}$ & & $0.262^{*}$ & 0.320 & 0.325 & & 0.255 & 0.294 \\
\hline \multirow[t]{2}{*}{$E S T^{*}$} & $\mathrm{He}$ & 0.720 & 0.723 & 0.725 & 0.752 & 0.819 & 0.768 & 0.715 \\
\hline & Ho & $0.476^{* *}$ & 0.667 & 0.600 & 0.650 & $0.474^{* *}$ & $0.536^{* *}$ & $0.585^{*}$ \\
\hline \multirow[t]{2}{*}{$G L D H^{*}$} & $\mathrm{He}$ & 0.651 & 0.538 & 0.647 & 0.649 & 0.470 & 0.569 & 0.631 \\
\hline & Ho & 0.632 & $0.462^{*}$ & 0.583 & $0.548^{*}$ & 0.591 & 0.612 & 0.558 \\
\hline \multirow{2}{*}{$P E P B-2^{*}$} & $\mathrm{He}$ & 0.109 & 0.079 & 0.058 & 0.066 & 0.184 & 0.136 & 0.107 \\
\hline & Ho & $0.023^{* *}$ & $0.058^{* *}$ & 0.059 & 0.067 & $0.040^{* *}$ & $0.061^{* *}$ & $0.022^{* *}$ \\
\hline \multirow[t]{2}{*}{$P G I-2^{*}$} & $\mathrm{He}$ & 0.000 & 0.072 & 0.179 & 0.021 & 0.041 & 0.060 & 0.044 \\
\hline & Ho & 0.000 & 0.074 & 0.190 & 0.021 & 0.041 & 0.061 & 0.044 \\
\hline \multirow[t]{2}{*}{$P G M^{*}$} & $\mathrm{He}$ & 0.067 & 0.041 & 0.070 & 0.021 & 0.080 & 0.060 & 0.022 \\
\hline & Ho & 0.068 & 0.042 & 0.071 & 0.021 & 0.082 & 0.061 & 0.022 \\
\hline \multirow[t]{2}{*}{$S D H^{*}$} & $\mathrm{He}$ & 0.454 & 0.425 & 0.497 & 0.531 & 0.653 & 0.426 & 0.522 \\
\hline & Ho & $0.313^{* *}$ & $0.341^{* *}$ & $0.548^{*}$ & 0.474 & 0.667 & 0.467 & $0.694^{*}$ \\
\hline
\end{tabular}

${ }^{\text {a }}$ Station of the samples (st.), see Fig. 1.

b Not scored.

${ }^{*} p<0.05$ significant departure from Hardy-Weinberg equilibrium.

${ }^{* *} p<0.005$ significant departure from Hardy-Weinberg equilibrium.

the Bonferroni procedure, only $16 \%$ of the samples deviated significantly, showing a deficit of heterozygosity. However, $f$ values were significantly higher than zero only for $A A T-2^{*}, E S T^{*}$ and $P E P B-2^{*}$ loci (Table 3).

The heterogeneity test $\theta$-statistics (Weir and Cockerham, 1984) revealed a heterogeneous genetic structure among the Mediterranean samples for the $E S T^{*}, G L D H^{*}, P G I-2^{*}$ and $S D H^{*}$ loci and a signifi-

Table 3

Weir and Cockerham (1984) F-statistics values in D. vulgaris $^{\mathrm{a}}$

\begin{tabular}{lccc}
\hline Locus & $f$ & \multicolumn{1}{l}{$F$} \\
\hline$A A T-2^{*}$ & $0.107^{*}$ & $0.106^{*}$ & -0.002 \\
$E S T^{*}$ & $0.202^{* *}$ & $0.212^{* *}$ & $0.013^{* *}$ \\
$G L D H^{*}$ & 0.064 & $0.085^{*}$ & $0.022^{* *}$ \\
$P E P B-2^{*}$ & $0.512^{* *}$ & $0.509^{* *}$ & -0.006 \\
$P G I-2^{*}$ & 0.064 & -0.017 & $0.014^{* *}$ \\
$P G M^{*}$ & -0.016 & -0.020 & -0.003 \\
$S D H^{*}$ & 0.033 & -0.050 & $0.018^{*}$ \\
Mean & $0.122^{* *}$ & $0.134^{* *}$ & $0.013^{* *}$
\end{tabular}

a The significance of $f$ and $F$ indicates the deficit of heterozygotes, while the significance of $\theta$ demonstrates the genetic heterogeneity of the samples.

$$
\begin{aligned}
& { }^{*} p<0.05 . \\
& { }^{* *} p<0.005 .
\end{aligned}
$$

cant difference in the average between all the samples (Table 3).

To examine the distribution of heterogeneity among the samples, genetic distances (Nei, 1978) were calculated and the values ranged from -0.0095 to 0.0466 . Neighbour joining clustering (Fig. 2a) showed that the Adriatic sample was widely isolated from all the others (Table 3).

\subsection{Lithognathus mormyrus}

A total of 20 loci was scored, 14 of which were monomorphic (AAT-1* $1^{*}$ EST-2,3* FUM $^{*}, L D H-1,2^{*}$, $M D H-1^{*}, P E P A-1,2^{*}, P E P B-1,2^{*}, P G I-1^{*}$ and $S D H^{*}$, $S O D^{*}$ and $\left.X D H^{*}\right)$ at a level of $95 \%$. Six polymorphic loci were identified: AAT-2* $E S T-1^{*}, G L D H^{*}$, $M D H-2^{*}, P G I-2^{*}$ and $P G M^{*}$. EST $-1^{*}$ was the most highly variable with seven alleles, whereas the other polymorphic loci were represented by three or two alleles (Table 4). The mean number of alleles per locus was 3.3.

Allelic frequencies for the six scored polymorphic loci are listed in Table 4. Observed $(\mathrm{Ho})$ and expected (He) heterozygosity plus the $\mathrm{H}-\mathrm{W}$ test are shown in Table 5. 


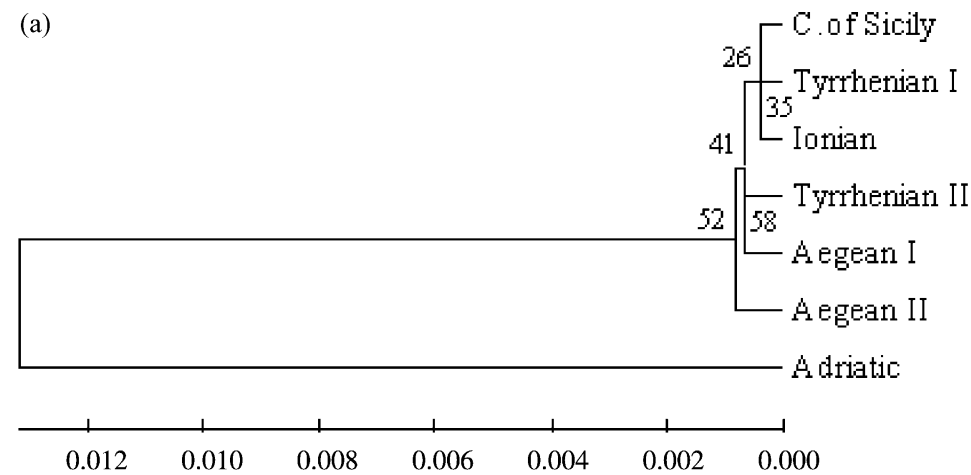

(b)

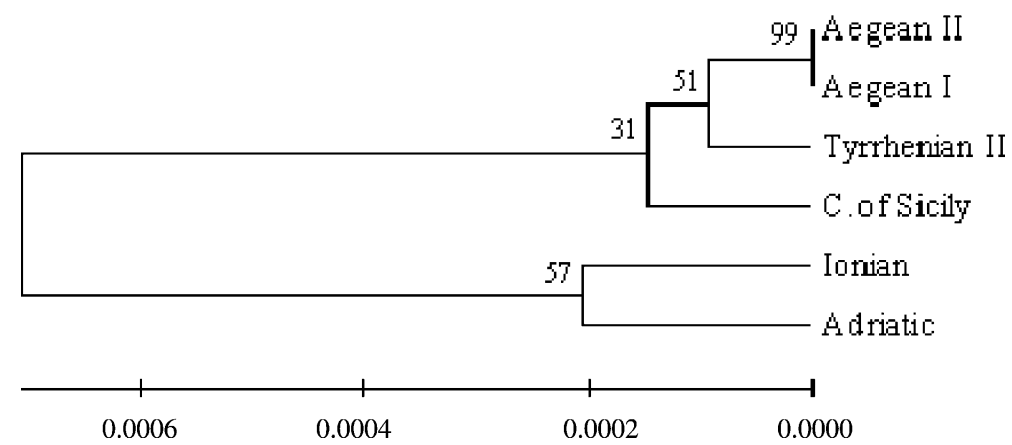

Fig. 2. Neighbor-joining dendrograms of (a) D. vulgaris and (b) L. mormyrus based on Nei's genetic distance (1978); number on nodes indicates percentage recovery of these nodes per 100 bootstrap replications.

Average overall observed heterozygosity overall loci was 0.069 and expected heterozygosity 0.072 (Table 5). Deviation from Hardy-Weinberg equilibrium for each locus was calculated and showed a low deficit of heterozygosites in two samples (Tyrrhenian Sea II and Aegean Sea II) for the AAT-2* and EST-1* loci (Table 5), the last of which deviated also after Bonferroni correction (Table 5).

Genotypic distribution and allele frequencies for polymorphic loci were substantially homogeneous. The genic differentiation, quantified using $F$-statistics of Weir and Cockerham (1984) for all samples, was not significant $(\theta=0.001, p>0.05$; Table 6).

Although the computation of Nei's distance (Nei, 1978) gave low values (between 0.0001 and 0.0008), the dendrogram obtained clustered the samples in two different groups: one of which comprising the Ionian and Adriatic samples (Fig. 2b).

\section{Discussion}

The analysis of protein-coding loci among the Mediterranean populations of two Sparidae species showed that $D$. vulgaris and L. mormyrus have a different pattern for the distribution of genetic variation on a large geographical scale.

A genetic population substructure was identified for $D$. vulgaris where $\theta$-statistics values were significant at four loci $\left(E S T^{*}, G L D H^{*}, P G I-2^{*}\right.$ and $\left.S D H^{*}\right)$ and for the mean value $(\theta=0.013, p<0.005)$ (Table 3). The dendrogram of genetic distances (Nei, 1978) of D. vulgaris, showed that the sample from Adriatic Sea was separated from the other sites (Fig. 2a), as a result of mechanisms that limit the gene exchange between the Adriatic and the other Mediterranean populations. According to Astraldi et al. (1999) the Adriatic Sea is a semi-closed 
Table 4

Frequencies of alleles found for each locus among the samples of L. mormyrus

\begin{tabular}{|c|c|c|c|c|c|c|c|c|}
\hline \multirow[t]{2}{*}{ Locus } & \multirow[t]{2}{*}{ Alleles } & & \multirow{2}{*}{$\begin{array}{l}\text { Tyrrhenian Sea II } \\
\text { st. } 2^{\text {a }}\end{array}$} & \multirow{2}{*}{$\begin{array}{l}\text { Channel of Sicily } \\
\text { st. } 3\end{array}$} & \multirow{2}{*}{$\begin{array}{l}\text { Ionian Sea } \\
\text { st. } 4\end{array}$} & \multirow{2}{*}{$\begin{array}{l}\text { Adriatic Sea I } \\
\text { st. } 5\end{array}$} & \multirow{2}{*}{$\begin{array}{l}\text { Aegean Sea I } \\
\text { st. } 7\end{array}$} & \multirow{2}{*}{$\begin{array}{l}\text { Aegean Sea II } \\
\text { st. } 8\end{array}$} \\
\hline & & & & & & & & \\
\hline \multirow[t]{3}{*}{$A A T-2^{*}$} & & $N^{\mathrm{b}}$ & 56 & 68 & 45 & 49 & 60 & 41 \\
\hline & 86 & & 0.384 & 0.404 & 0.378 & 0.439 & 0.325 & 0.329 \\
\hline & 100 & & 0.616 & 0.596 & 0.622 & 0.561 & 0.675 & 0.671 \\
\hline \multirow[t]{8}{*}{$E S T-1^{*}$} & & $N$ & 64 & 68 & 43 & 50 & 59 & 41 \\
\hline & 95 & & 0.016 & 0.015 & & & 0.008 & 0.012 \\
\hline & 98 & & 0.039 & 0.015 & 0.047 & 0.050 & 0.042 & 0.037 \\
\hline & 100 & & 0.664 & 0.684 & 0.721 & 0.670 & 0.576 & 0.695 \\
\hline & 102 & & 0.063 & 0.088 & 0.047 & 0.030 & 0.093 & 0.098 \\
\hline & 104 & & 0.109 & 0.132 & 0.081 & 0.170 & 0.153 & 0.073 \\
\hline & 106 & & 0.086 & 0.029 & 0.093 & 0.080 & 0.059 & 0.049 \\
\hline & 107 & & 0.023 & 0.037 & 0.012 & & 0.068 & 0.037 \\
\hline \multirow[t]{4}{*}{$G L D H^{*}$} & & $N$ & 56 & 64 & 42 & 41 & 55 & 36 \\
\hline & 97 & & 0.179 & 0.164 & 0.214 & 0.220 & 0.109 & 0.069 \\
\hline & 100 & & 0.821 & 0.828 & 0.786 & 0.780 & 0.891 & 0.931 \\
\hline & 102 & & & 0.008 & & & & \\
\hline \multirow[t]{4}{*}{$M D H-2^{*}$} & & $N$ & 73 & 74 & 50 & 50 & 60 & 41 \\
\hline & 80 & & 0.027 & 0.007 & 0.040 & 0.020 & 0.025 & 0.049 \\
\hline & 100 & & 0.966 & 0.993 & 0.950 & 0.980 & 0.967 & 0.951 \\
\hline & 130 & & 0.007 & & 0.010 & & 0.008 & \\
\hline \multirow[t]{4}{*}{$P G I-2^{*}$} & & $N$ & 38 & 60 & & 50 & 43 & 41 \\
\hline & 92 & & 0.039 & 0.017 & n.s. ${ }^{c}$ & 0.050 & 0.035 & 0.037 \\
\hline & 100 & & 0.961 & 0.975 & & 0.950 & 0.965 & 0.939 \\
\hline & 108 & & & 0.008 & & & & 0.024 \\
\hline \multirow[t]{3}{*}{$P G M^{*}$} & & $N$ & 37 & 60 & & 50 & 60 & 41 \\
\hline & 100 & & 0.959 & 0.967 & n.s. & 0.960 & 0.975 & 0.988 \\
\hline & 118 & & 0.041 & 0.033 & & 0.040 & 0.025 & 0.012 \\
\hline
\end{tabular}

${ }^{\text {a }}$ Station of the samples (st.), see Fig. 1.

${ }^{\mathrm{b}}$ Number of genotypes scored.

${ }^{\mathrm{c}}$ Not scored.

area with peculiar oceanographic characteristics, which seem to influence the distribution of allelic frequencies in other fish species, like the European anchovy Engraulis encrasicolus (Bembo et al., 1996) and the common sole Solea vulgaris (Kotoulas et al., 1995), in which genetic differences were found. Nevertheless, the intraspecific genetic substructure of $D$. vulgaris, was supported by the significant heterogeneity among each pair of samples (as calculated by the pairwise Fisher's exact test) (data not showed), showing the heterogeneity in all the samples analysed.

Genotypic frequencies for $D$. vulgaris showed a deviation from expectations for Hardy-Weinberg equilibrium and a significant deficit of heterozygosity was observed $(f=0.122, p<0.005)$ in many of the loci analysed (Table 2). This may be the result of selective forces against heterozygotes in the sys- tem. On the other hand, the Wahlund effect (Hartl and Clark, 1989), by which the presence of different genetic stocks in a single sample can cause an excess of homozygotes, could be a plausible explanation. The mixture of different populations with different allozyme frequencies (Wahlund effect) is common in marine species (Sanjuan et al., 1994; Mamuris et al., 1998) due to difficulties in identifying the boundaries of different demes. The other possible causes of this deficiency may be inbreeding, assortative mating or null allele. The first two aspects could be excluded because inbreeding should display the deficit across all polymorphic loci, whereas assortative mating should be influenced by male and female courtship or interaction before release of eggs; in this last case the spawning behaviour of $D$. vulgaris is completely random. Finally, no homozygotes for null alleles were observed. 
Table 5

Observed $(\mathrm{Ho})$ and unbiased expected $(\mathrm{He})$ heterozygosity for each locus in L. mormyrus

\begin{tabular}{|c|c|c|c|c|c|c|c|}
\hline \multirow[t]{2}{*}{ Locus } & & Tyrrhenian Sea II & \multirow{2}{*}{$\begin{array}{l}\text { Channel of Sicily } \\
\text { st. } 3\end{array}$} & \multirow{2}{*}{$\begin{array}{l}\text { Ionian Sea } \\
\text { st. } 4\end{array}$} & \multirow{2}{*}{$\begin{array}{l}\text { Adriatic Sea I } \\
\text { st. } 5\end{array}$} & \multirow{2}{*}{$\begin{array}{l}\text { Aegean Sea I } \\
\text { st. } 7\end{array}$} & \multirow{2}{*}{$\begin{array}{l}\text { Aegean Sea II } \\
\text { st. } 8\end{array}$} \\
\hline & & st. $2^{\mathrm{a}}$ & & & & & \\
\hline \multirow[t]{2}{*}{$A A T-2^{*}$} & $\mathrm{He}$ & 0.477 & 0.485 & 0.475 & 0.498 & 0.442 & 0.447 \\
\hline & $\mathrm{Ho}$ & $0.339^{*}$ & 0.426 & 0.400 & 0.510 & 0.417 & 0.463 \\
\hline \multirow[t]{2}{*}{$E S T-1^{*}$} & $\mathrm{He}$ & 0.538 & 0.508 & 0.466 & 0.518 & 0.631 & 0.503 \\
\hline & Ho & 0.476 & 0.500 & 0.512 & 0.480 & 0.610 & $0.317^{* *}$ \\
\hline \multirow[t]{2}{*}{$G L D H^{*}$} & $\mathrm{He}$ & 0.250 & 0.289 & 0.341 & 0.347 & 0.196 & 0.131 \\
\hline & $\mathrm{Ho}$ & 0.296 & 0.281 & 0.333 & 0.439 & 0.182 & 0.139 \\
\hline \multirow[t]{2}{*}{$M D H-2^{*}$} & $\mathrm{He}$ & 0.067 & 0.014 & 0.097 & 0.040 & 0.065 & 0.094 \\
\hline & $\mathrm{Ho}$ & 0.068 & 0.014 & 0.100 & 0.040 & 0.067 & 0.098 \\
\hline \multirow[t]{2}{*}{$P G I-2^{*}$} & $\mathrm{He}$ & 0.079 & 0.049 & n.s. ${ }^{b}$ & 0.096 & 0.068 & 0.118 \\
\hline & Ho & 0.077 & 0.050 & & 0.100 & 0.070 & 0.122 \\
\hline \multirow[t]{2}{*}{$P G M^{*}$} & $\mathrm{He}$ & 0.079 & 0.065 & n.s. & 0.078 & 0.049 & 0.024 \\
\hline & Ho & 0.081 & 0.067 & & 0.080 & 0.050 & 0.024 \\
\hline
\end{tabular}

${ }^{\text {a }}$ Station of the samples (st.), see Fig. 1.

${ }^{\mathrm{b}}$ Not scored.

${ }^{*} p<0.05$ significant departure from Hardy-Weinberg equilibrium.

${ }^{* *} p<0.005$ significant departure from Hardy-Weinberg equilibrium.

The values of $\theta$ found in $D$. vulgaris suggested that the samples should be considered as distinct subpopulations; the values of $\theta$ fall within the range of values $(\theta=0.002-0.079)$ found in other fish species in the Mediterranean basin (Borsa et al., 1997; Mamuris et al., 1998), thereby reflecting the common degree of geographic differentiation in this area.

The geographical structure of populations could be affected by local conditions and species life-history (Borsa et al., 1997; Sinclair, 1988), and it follows that, the potential for species dispersal may not always predict the amount of gene flow among pop-

Table 6

Weir and Cockerham (1984) $F$-statistics values in L. mormyrus ${ }^{\mathrm{a}}$

\begin{tabular}{lccr}
\hline Locus & $f$ & \multicolumn{1}{l}{$F$} \\
\hline$A A T-2^{*}$ & $0.103^{*}$ & $0.101^{*}$ & -0.002 \\
$E S T-1^{*}$ & $0.080^{* *}$ & $0.081^{*}$ & 0.001 \\
$G L D H^{*}$ & 0.002 & 0.014 & 0.012 \\
$M D H-2^{*}$ & -0.026 & -0.026 & 0.000 \\
$P G I-2^{*}$ & -0.031 & -0.036 & -0.004 \\
$P G M^{*}$ & -0.024 & -0.030 & -0.006 \\
Mean & $0.059^{*}$ & $0.060^{*}$ & 0.001 \\
\hline
\end{tabular}

a The significance of $f$ and $F$ indicates the deficit of heterozygotes, while the significance of $\theta$ demonstrates the genetic heterogeneity of the samples.

$$
\begin{aligned}
& * p<0.05 \text {. } \\
& { }^{* *} p<0.005 .
\end{aligned}
$$

ulations (Palumbi, 1995). This is particularly true if we consider that physical or oceanographic barriers to gene flow are not relevant over the whole Mediterranean basin (Borsa et al., 1997; Lo Brutto et al., 1998). In this respect, D. vulgaris is a species closely associated with brackish environments, like lagoons, where ecological factors may have selective pressure on genotypes (Cognetti and Maltagliati, 2000). Thus, selective factors could affect local demes and determine genetic heterogeneity within the species. This hypothesis should be confirmed by further analysis on D. vulgaris, including a more accurate plan of sampling and the use of different molecular markers.

In contrast, the genotypic distribution and allele frequencies in L. mormyrus, were substantially homogeneous, as showed by the $\theta$-statistics (Table 6). The homogeneity were showed also by the low values of genetic distances (ranging from 0.0001 to 0.0008 ), as compared with those of D. vulgaris (Fig. 2), even if two different clusters were described by the dendrogram, where the Adriatic and Ionian samples were separated from the others (Fig. 2b).

A lack of genetic structuring for L. mormyrus, indicates a unique gene pool and a single panmitic population of this species. This result was also supported during preliminary research where the comparison of electrophoresis, otolith readings and growth parameters from three sample sites along the sicilian coasts 
and one from Greece coasts showed no significant differences between them (Arculeo et al., 1999).

In conclusion, our genetic data suggest two scenarios where $D$. vulgaris and $L$. mormyrus are represented, respectively, by separate breeding populations and by a single gene pool. This finding is particularly relevant for management decisions on a strategy to ensure sustainable utilisation of both species. Moreover, it should be emphasised that among priorities for future studies should be the genetic analysis of mitochondrial or nuclear DNA markers and that further investigation are warranted such as the collection of samples from putative spawning grounds.

\section{Acknowledgements}

This research was partially supported by European Community (EC XIV, Project no. 96/054) and MURST 60\%. We thank Drs. E. Arneri, F. Grim, A. Kallianiotis, A. Potoschi and F. Serena for obtaining samples.

\section{References}

Alarcón, J.A., Alvarez, M.C., 1999. Genetic identification of sparid species by isozyme markers: application to interspecific hybrids. Aquaculture 173, 95-103.

Arculeo, M., Cannizzaro, L., Kallianotis, A., Potoschi, A., Lo Brutto, S., Parrinello, N., Bono, G., Sophronidis, K., Celesti, A., Gancitano, S., 1999. Allozymic and morphometric analysis of Lithognatus mormyrus (Pisces, Sparidae) in the Mediterranean Sea. In: Proceedings of the 34th European Marine Biology Symposium, vol. 97, Ponte Del Gada, Azores, Portugal, September 1999.

Astraldi, M., Balopoulos, S., Candela, J., Font, J., Gacic, M., Gasparini, G.P., Manca, B., Theocharis, A., Tintoré, J., 1999. The role of straits and channels in understanding the characteristics of Mediterranean circulation. Progr. Ocean. 44, 65-108.

Basaglia, F., 1991. Interspecific gene differences and phylogeny of the Sparidae family (Perciformes, Teleostei), estimated from electrophoretic data on enzymatic tissue expression. Comp. Biochem. Physiol. B 99, 495-508.

Bembo, D.G., Carvalho, G.R., Cingolani, N., Arneri, E., Giannetti, G., Pitcher, T.J., 1996. Allozymic and morphometric evidence for two stocks of the European anchovy Engraulis encrasicolus in Adriatic waters. Mar. Biol. 126, 529-538.

Borsa, P., Planquer, A., Berrebi, P., 1997. Genetic structure of the flounders Platichthys flesus and P. stellatus at different geographic scales. Mar. Biol. 129, 233-246.
Carvalho, G.R., Hauser, L., 1995. Molecular genetics and the stock concept in fisheries. In: Carvalho, G.R., Pitcher, T.J. (Eds.), Molecular Genetics in Fisheries. Chapman \& Hall, London, pp. 55-79.

Cognetti, G., Maltagliati, F., 2000. Biodiversity and adaptive mechanisms in brackish water fauna. Mar. Pollut. Bull. 40 (1), 7-14.

Davis, B.J., 1964. Methods and Application to Human Serum Protein. Annales Academiae Scientiarum, New York.

Felsenstein, J., 1985. Confidence limits on phylogenies: an approach using the bootstrap. Evolution 39, 783-791.

Goudet, J., 1995. FSTAT version 1.2: a computer program to calculate $F$-statistics. J. Hered. 86, 485-486.

Hartl, D.L., Clark, A.G., 1989. Principles of Population Genetics. Sinauer Associates, Sunderland, Massachusetts.

Kotoulas, G., Bonhomme, F., Borsa, P., 1995. Genetic structure of the common sole Solea vulgaris at different geographic scales. Mar. Biol. 122, 361-375.

Kumar, S., Tamura, K., Jakobsen, I.B., Nei, M., 2001. MEGA2: Molecular Evolutionary Genetics Analysis Software. Arizona State University, Tempe, Arizona.

Lessions, H.A., 1992. Testing electrophoretic data for agreement with Hardy-Weinberg expectations. Mar. Biol. 112, 517523.

Lo Brutto, S., Arculeo, M., Mauro, A., Scalisi, M., Cammarata, M., Parrinello, N., 1998. Allozymic variation in Mediterranean hake Merluccius merluccius (Gadidae). Italian J. Zool. 65 (Suppl.), 49-52.

Mamuris, Z., Apostolidis, A.P., Triantaphyllidis, C., 1998. Genetic protein variation in red mullet (Mullus barbatus) and striped red mullet (M. surmuletus) populations from the Mediterranean Sea. Mar. Biol. 130, 353-360.

Nei, M., 1978. Estimation of average heterozygosity and genetic distance from a small number of individuals. Genetics $89,583-$ 590.

Palumbi, S.R., 1995. Using genetics as an indirect estimator of larval dispersal. In: McEdward, L.R. (Ed.), Ecology of Marine Invertebrate Larvae. CRC Press, Boca Raton, FL, pp. 369-387.

Raymond, M., Rousset, F., 1995. GENEPOP (version 1.2): population genetic software for exact tests and ecumenism. J. Hered. 86, 248-249.

Reina, J., Martinez, G., Amores, A., Alvarez, M.C., 1994. Interspecific genetic differentiation in Western Mediterranean sparid fish. Aquaculture 125, 47-57.

Richardson, B.J., Baverstock, P.R., Adams, M., 1986. Allozyme Electrophoresis. Academic Press, San Diego, CA.

Sanjuan, A., Zapata, C., Alvarez, G., 1994. Mytilus galloprovincialis and M. edulis on the coasts of Iberian Peninsula. Mar. Ecol. Prog. Ser. 113, 131-146.

Shaklee, J.B., Allendorf, F., Morizot, D.C., Whitt, G.S., 1990. Gene nomenclature for protein-coding loci in fish. Trans. Am. Fish. Soc. 119, 2-15.

Sinclair, M., 1988. Marine Populations: an Essay on Population Regulation and Speciation. University of Washington Press, Seattle.

Weir, B.S., Cockerham, C.C., 1984. Estimating $F$-statistics for the analysis of population structure. Evolution 38, 1358-1370. 